adventurous spirits who will roam away and, through contact with the whites, lose touch with the old life. These newly detribalized men should be assisted to maintain themselves as respectable members of the community and to do suitable work, as much in the country as possible, on the cattle and sheep stations. They should be under some sort of supervision and be encouraged to keep up their tribal customs and corroborees.

The completely detribalized aborigines of long. standing separation from their own communities are a more difficult problem, having mostly become urbanized and of mixed blood. Prof. Cleland con siders that they should not be segregated from the whites and regarded as inferiors, but should be educated to become good citizens and take their share of community life.

K. Rishbeth.

\section{PREHISTORY IN THE CONGO*}

$\mathrm{T}$ HE prehistoric archæology of the Congo is very little known. The researches of Dr. Cabu were in part published at the International Congress held in Brussels in 1935; but most of his discoveries are still unknown to the average prehistorian. Yet the Congo is probably a key area, linking as it does the north with the south of the African continent. The only bit of information on the subject which had become current among prehistorians concerned an alleged new culture, the Tumbrian; but now even this latter seems actually to be non-existent, and the industry in question merely a mélange of early, middle and later stone age material, somewhat corresponding to the Sangoan of Uganda.

It is, therefore, of very great interest to have such studies as these under notice from the pens of prehistorians of the eminence of Profs. Breuil and van Riet Lowe. Alas, there are no illustrations. Both Breuil's articles are technical, and describe in detail the industries found at a number of stone age sites and their cultural affinities. An intriguing reference occurs at the end to discoveries of painted rockshelter sites. The paintings are in red and conventionalized. Prof. van Riet Lowe also describes in detail the industries and compares them with those occurring in South Africa and in the Uganda-Kenya regions. $\mathrm{He}$, too, claims that the Tumbrian consists of "advanced Acheul, La Micoque and Combe Capelle bifaced tools (i.e., Fouresmith), ? protoStillbay, Sangoan picks, Stillbay points, Aterian and Sbäikian bifaced points (including pedunculate forms), ground and polished axes and pottery"; quite a mixture! He also notes the occurrence of Smithfield tools. This reinforces the contention that this culture is not purely a South African product, and backs up Archdeacon Owen's finds of a Smithfield industry in western Kenya.

Quite obviously we shall have to await the end of the War for a full account of the prehistory of the Congo. But enough is here given to make it clear that this important area is likely to be critical for any general appreciation of the Stone Ages in Africa.

M. C. BuRKITT.

- "Le Paléolithique du Congo Belge d’après les recherches du Docteur Cabu". By l'A hbé Henri Breuil.

'Les industries palénlithiques de la terrasse de 15 Metres et d'un chenal secondaire comble, Plaine de Piemont de Leopoldville, d'après les fouilles et photographies du Docteur Cabu". By l'Abbé Henri Breuil.

"Notes on Dr. Francis Cabu's Collection of Stone Implements from the Belgian Congo". By Dr. C. van Riet Lowe.

Reprinted from Trans. Roy. Soc. S. Africa, 30, Pt. 2 (1944).

\section{STRAY LOSSES IN SYNCHRONOUS ELECTRICAL MACHINERY}

D. RICHARDSON, in a paper read before the Institution of Electrical Engineers in London recently, discusses the problem of eddy currents from the point of view of the effect of the physical arrangement of an alternator on the stray losses, and deals afterwards with the components of stray loss. Since the latter can be classified conveniently in accordance with their position in the alternator, the stray losses which occur in the stator are considered first.

It is shown how the arrangement of the endwindings influences the shape of the end leakage field and thus the intensity of loss in the adjacent metallic structures, and how the loss in the.coreend-plate can be estimated. The effect of magnetic and non-magnetic shielding arrangements is discussed, together with details of their arrangement. Experiments in connexion with eddy-current losses in the stator end connexions are described. Consideration is given to the iron loss which occurs in the stator core under steady three-phase shortcircuit conditions owing to the flux-wave shape, and the indications are that this provides at least a partial explanation of why the stray losses can be so appreciably greater on short-circuit than on load.

The stray losses in the rotor, generally grouped under the heading of rotor surface losses, are shown to be due to several effects, notably to the concentration of ampere-conductors in one slot and to the irregularities present in the stator magnetomotive force wave. Consideration is also given to the surface or pole-face losses resulting from the 'tufting' of flux under the stator teeth, which loss is experienced under conditions of no load and is normally measured with the stator iron loss. The factors affecting the surface losses are discussed, together with methods for reducing the losses to a minimum. An indication is given of the relationship between the stray losses at the ends and those located within the core-length of an alternator, together with a description of the effect of load conditions on each of the components of stray loss.

\section{FORTHCOMING EVENTS}

Saturday, May 12

Institution of the RUBber IndUSTRY (Midiand SeOtion) (at the Imperial Hotel, Birmingham), at 10 a.m. and 2 p.m.-Symposium on "The Physical and Chemical Breakdown of Rubber".

Monday, May 14

Association of austrian Engingers, Chemists and Soientific WORKFRS IN GREAT BRITAIN (joint meeting with the ROYAL NETHERLAND INSTTTUTION OF CIVII ENGINEERS AND THE SOCIETY OF DANISH Crvin ENGINEFrs) (at the Institution of Structural Engineers, 11 , Upper Belgrave Street, London, S.W 1), at 6.30 p.m.- - Prof. K. W' Mautner : "Extension Work on the Harbour of Dunkirk, 1930-1938" (Lantern Lecture).

Tuesday, May 15

ROYAL SOCIETY OF ARTS (DoMINIONS AND CoLONIES SECTION (ioint meeting with the ROYAL AFrICAN SOCIFTY) (at John Adam (ioint meeting with the ROYAL AFrICAN SOCIETY) Malcolm Guthrie : "Etreet, Adelphi, London, W.C.2), at 1.45 p.m.- Africa's Reactions to European Culture".

INSTITUTION OF ELEOTRICAL ENGINEERS (RADIO SEOTION) (at Savoy Place, Victoria Embankment, London, W.C.2), at 5.30 p.m.-Discussion on "The Characteristics of Luminescent Materials for CathodeRay Tubes" (to be opened by Mr. C. G. A. Hill).

Wednesday, May 16

ROYAL SOCLETY of ARTS (at John Adam Street, Adelphi, London, ROYAL SocIETY OF ARTS (at John Adam Street, "Adelph, Social RelaW.C.2), at 1.45 p.m.- - Prof. J. D. Bernal, F.

GEOLOGIOAL SOCIETX OF LONDON (at Burlington House, Piccadilly, London, W.1), at 3 p.m.--Scientific Papers. 